\title{
PENGEMBANGAN PERANGKAT PMR DAN PENGARUHNYA TERHADAP HASIL BELAJAR MATEMATIKA PADA SISWA KELAS VIII SMP KATOLIK AMBON (Kajian Masalah Materi Bangun Ruang Sisi Datar)
}

\author{
Helena Mataheru \\ Program Studi Magister Pendidikan Matematika, Pascasarjana, Universitas Pattimura \\ Jalan Ir. Putuhena, Kampus Unpatti, Poka, Ambon, Indonesia \\ e-mail: helenamataheru@gmail.com; \\ Submitted: August 25, 2020 \\ Revised: September 27, 2020 \\ Accepted: September 29, 2020 \\ corresponding author*
}

\begin{abstract}
Abstrak
Penelitian ini bertujuan untuk: (1) Menghasilkan perangkat pembelajaran matematika realistik yang baik/valid untuk materi bangun ruang sisi datar pada siswa kelas VIII SMP Katolik Ambon. (2) Mengetahui pengaruh penggunaan perangkat pembelajaran matematika realistik terhadap hasil belajar matematika untuk materi bangun ruang sisi datar pada siswa kelas VIII SMP Katolik Ambon. Penelitian ini merupakan penelitian eksperimen yang diawali dengan penelitian pengembangan, yakni untuk menghasilkan perangkat pembelajaran yang berorientasi pada pembelajaran matematika realistik (PMR) untuk materi pokok Bangun Ruang Sisi Datar di SMP kelas VIII. Proses pengembangan perangkat pembelajaran mengikuti tahap pengembangan perangkat pembelajaran model 4-D Thiagarajan yang telah dimodifikasi tanpa penyebaran (disseminate). Hasil pengembangan perangkat pembelajaran dengan pendekatan PMR yaitu Rencana Pelaksanaan Pembelajaran (RPP), Bahan Ajar (BA), Lembar Kerja Siswa (LKS) dan Tes Hasil Belajar (THB). Sedangkan eksperimen digunakan untuk menggambarkan keefektifan pembelajaran dengan pendekatan Pendidikan Matematika Realistik (PMR) dan membandingkan hasil belajar antara siswa yang mengikuti pembelajaran dengan pendekatan PMR dengan siswa yang mengikuti pembelajaran konvensional pada materi bangun ruang sisi datar. Dari hasil analisis yang dilakukan oleh peneliti diperoleh: 1) perangkat pembelajaran dengan pendekatan PMR pada materi bangun ruang sisi datar telah memenuhi kriteria perangkat pembelajaran yang baik/valid karena dinyatakan oleh: rata-rata penilaian validator baik, aktivitas guru dalam mengelola pembelajaran terlaksana, aktivitas siswa terlaksana, respon guru terhadap perangkat pembelajaran positif, respon siswa terhadap pembelajaran positif, dan persentase rata-rata siswa yang mencapai KKM 79\% dari jumlah siswa di kelas. 2) hasil belajar siswa meningkat berdasarkan analisis statistik inferensial sehingga dapat disimpulkan bahwa ada pengaruh pengembangan perangkat pembelajaran matematika realistik terhadap hasil belajar matematika untuk materi bangun ruang sisi datar pada siswa kelas VIII SMP Katolik Ambon
\end{abstract}

Kata Kunci: pengembangan perangkat pembelajaran, pendidikan matematika realistik

\begin{abstract}
This study aimed at: 1) producing a valid learning material of realistic mathematic for flat space solid edge material at VIII grade students of SMP Katolik Ambon; 2) finding out the effect of using learning material of mathematic realistic toward learning outcome for flat space solid edge material at VIII grade students of SMP Katolik Ambon. This study was an experiment research initialized by conducting development research to produce learning material oriented to realistic mathematic learning for flat space solid edge material at VIII grade. The development process of learning material followed the procedure of Thiagarajan 4-D model of development that had been modified without dissemination. The results of learning material development with realistic mathematic learning approach were lesson plan, learning material, students' worksheet and learning outcome test, while the experiment was used to describe the learning effectiveness with realistic mathematic learning approach and to compare learning outcome between students who followed learning process with realistic mathematic learning approach and students who learnt conventionally for flat space solid edge material. The results showed that: 1) learning material with realistic mathematic learning approach for flat space solid edge material had fulfilled the criteria which was show by good expert validation, teachers' activity in managing learning process, students' activity, positive responses of teachers and students toward learning material and the average percentage of students learning outcome achieving $79 \%$ of whole students in the class; 2) students learning outcome was increased based
\end{abstract}

Copyright ( $\odot$ Authors. This is an open access article distributed under the Attribution-NonCommercialShareAlike 4.0 International (CC BY-NC-SA 4.0), which permits unrestricted use, distribution, and reproduction in any medium, provided the original work is properly cited. 
on analysis of inferential statistic, so it could be concluded that the development of learning material of realistic mathematic affected students learning outcome for flat space solid edge material at VIII grade students of SMP Katolik Ambon

Keywords: the development of learning material, realistic mathematic education

\section{Pendahuluan}

Matematika merupakan ilmu universal yang mendasari perkembangan teknologi modern dan mempunyai peran penting dalam berbagai disiplin ilmu dan mengembangkan daya pikir manusia. Untuk menguasai dan mencipta teknologi di masa depan diperlukan penguasaan matematika yang kuat sejak dini. Menurut Horbi (2008: 151) bahwa matematika sebagai ilmu dasar memegang peranan yang sangat penting dalam pengembangan sains dan teknologi, karena matematika merupakan sarana berpikir untuk menumbuhkembangkan daya nalar, cara berpikir logis, sistematis, dan kritis.

Berbicara tentang pembelajaran matematika di sekolah, tidak terlepas dari masalah-masalah yang terdapat didalamnya. Pembelajaran yang diterapkan di sekolah masih cenderung bersifat konvensional. Kenyataannya bahwa guru kurang melibatkan aktivitas siswa menyebabkan siswa tidak bebas mengeluarkan ide-idenya karena pembelajaran didominasi oleh guru. Siswa banyak menghafal konsep matematika yang diberikan guru dan menyelesaikan masalah secara prosedural. Dengan situasi ini siswa secara pasif menerima pengetahuan matematika sebagai barang jadi yang ditransfer oleh gurunya. Mereka cukup menghafalkan prosedur lalu menerapkan pada soal yang sesuai. Apa yang akan terjadi jika ternyata di lapangan nanti siswa menemukan masalah yang belum pernah dibicarakan prosedur pemecahannya? Tentu saja dia akan gagal menyelesaikan masalah tersebut. Siswa secara pasif menerima pelajaran yang diberikan gurunya sebagai barang jadi. Namun jika siswa dibekali dengan kemampuan berpikir logis dan analitis maka dia akan mampu secara kritis dan kreatif menemukan pemecahan masalah tersebut. Untuk itu perlu ditinjau pandangan konstruktivisme. Melalui interaksi dengan hal-hal yang nyata inilah diharapkan siswa dapat mengkonstruksi pengetahuannya. Salah satu pendekatan dalam pembelajaran matematika yang menekankan penggunaan masalah nyata dalam langkah-langkah membangun pengetahuan adalah Pembelajaran Matematika Realistik (PMR).

Geometri merupakan cabang matematika yang diajarkan di sekolah untuk tujuan menumbuhkembangkan lima kemampuan dasar siswa, yaitu: visual, verbal, menggambar, berlogika dan penerapan (Mursalim, 2016: 251). Lebih lanjut dikatakan bahwa disamping menonjol pada objek yang abstrak dan struktur berpola deduktif, geometri juga menonjol pada teknikteknik geometri yang efektif dalam membantu penyelesaian problema dari banyak cabang matematika, sehingga sering dikatakan bahwa geometri esensial bagi setiap pokok bahasan matematika sekolah pada setiap jenjang pendidikan. Sifat visual dan representasinya menjadikan geometri dapat mendukung siswa untuk memahami konsep bilangan dan pengukuran. Aktivitas pemecahan masalah dalam geometri merupakan aktivitas yang baik untuk perkembangan berpikir siswa karena berhubungan dengan ruang, konstruktif, serta terkait dengan dunia nyata.

Dalam geometri dibahas objek-objek yang berhubungan dengan ruang dari berbagai dimensi. Geometri bangun ruang dimensi tiga mempelajari tentang bangun ruang sisi datar yakni kubus, balok, prisma, dan limas yang sering ditemukan dalam kehidupan nyata dan sangat bermanfaat bagi siswa. Akan tetapi dalam realitanya, pemahaman siswa terhadap materi geometri ini masih belum optimal, yang pada akhirnya sangat berpengaruh terhadap hasil belajar.

Hasil pra-penelitian yang peneliti lakukan di SMP Katolik Ambon, menunjukkan bahwa guru belum mengembangkan perangkat pembelajaran secara mandiri. Masih sangat jarang ditemukan perangkat pembelajaran yang dapat memfasilitasi siswa untuk membangun pengetahuannya. Rencana Pelaksanaan Pembelajaran (RPP) dan Bahan Ajar (BA) dibuat secara umum dan belum diperinci pada tiap kegiatannya. Lembar Kerja Siswa (LKS), yang digunakan berasal dari penerbit yang berisi ringkasan materi dan kumpulan soal sehingga kurang memberikan motivasi kepada siswa untuk aktif dalam pembelajaran.

Cara penyajian seperti ini menimbulkan kesan bahwa guru cenderung mendominasi kegiatan pembelajaran dan siswa kadang-kadang tidak memahami apa yang mereka kerjakan. Selain itu, salah satu yang sering dikeluhkan dalam dunia pendidikan matematika adalah kurangnya keterkaitan matematika di sekolah dengan dunia nyata dan kehidupan sehari-hari siswa. Padahal dalam pengajaran matematika terutama diarahkan 
agar siswa memahami konsep dan keterampilan berhitung melalui serangkaian kegiatan praktis yang dilakukan sendiri oleh siswa.

Agar dapat melaksanakan pembelajaran matematika realistik untuk materi bangun ruang sisi datar maka dibutuhkan perangkat pembelajaran yang sesuai dengan teori pembelajaran matematika realistik. Dengan demikian perlu dikembangkan perangkat pembelajaran matematika realistik yang baik, sesuai dengan langkah-langkah dalam model pengembangan perangkat yang tentunya berpengaruh terhadap hasil belajar siswa.

Berdasarkan penjelasan di atas, tujuan dalam penelitian ini adalah: (1) Menghasilkan perangkat pembelajaran matematika realistik yang baik/valid untuk materi bangun ruang sisi datar pada siswa kelas VIII SMP Katolik Ambon. (2) Mengetahui pengaruh penggunaan perangkat pembelajaran matematika realistik terhadap hasil belajar matematika untuk materi bangun ruang sisi datar pada siswa kelas VIII SMP Katolik Ambon.

\section{Metode Penelitian}

Penelitian ini termasuk penelitian eksperimen yang diawali dengan pengembangan perangkat pembelajaran berupa rencana pelaksanaan pembelajaran (RPP), bahan ajar (BA), dan lembar kegiatan siswa (LKS) untuk materi bangun ruang sisi datar. Setelah perangkat pembelajaran dikembangkan, dilaksanakan penelitian eksperimen untuk mengetahui ada tidaknya pengaruh terhadap hasil belajar matematika dengan menggunakan perangkat pembelajaran yang telah dikembangkan tersebut yakni perangkat pembelajaran matematika realistik (PMR) untuk materi bangun ruang sisi datar pada siswa kelas VIII SMP Katolik Ambon.

Model pengembangan yang akan digunakan untuk mengembangkan perangkat pembelajaran dalam penelitian ini adalah modifikasi dari model Thiagarajan yang dikenal dengan Four-D Models (Model 4-D). Karena adanya berbagai keterbatasan, maka pengembangan ini dibatasi hanya sampai pada tahap pengembangan (develop), yakni sampai pada kegiatan uji coba perangkat pembelajaran.

\section{Pengembangan Perangkat}

Tahapan pengembangan perangkat pembelajaran dalam penelitian ini terdiri dari:

Tahap pendefinisian (Define). Pada tahap ini dilakukan beberapa hal yaitu: (a) Analisis awal akhir yang dilakukan untuk memunculkan masalah dasar yang dihadapi dalam pengembangan perangkat pembelajaran, (b) Analisis siswa yang dilakukan mengetahui karakteristik siswa kelas VIII SMP Katolik Ambon seperti kemampuan akademik, sehingga rancangan perangkat pembelajaran yang akan dikembangkan dapat disesuaikan dengan karakteristik tersebut, (c) Analisis materi yang bertujuan memerinci dan menyusun secara sistematis materi bangun ruang sisi datar, yakni luas permukaan dan volume kubus, balok, prisma, dan limas, dengan materi prasyarat yang relevan untuk diajarkan sesuai dengan hasil analisis awal-akhir, (d) Analisis tugas dilakukan untuk mengidentifikasi berbagai keterampilan utama yang diperlukan dalam pembelajaran yang akan dikembangkan dalam perangkat pembelajaran. Analisis tugas ini disusun berdasarkan standar kompetensi dan indikator pencapaian hasil belajar untuk materi bangun ruang sisi datar. (e) Spesifikasi tujuan pembelajaran sebagai dasar mengkonstruksi tes dan desain pembelajaran.

Tahap perancangan (Design). Pada tahap ini, peneliti melakukan beberapa kegiatan yaitu: (a) Pemilihan media bertujuan untuk memilih media yang tepat dan sesuai dengan isi pembelajaran, yaitu penyesuaian antara analisis materi, analisis tugas, dan karakteristik siswa. Media yang digunakan berupa papan tulis, alat tulis dan media cetak lainnya. (b) Pemilihan format. Format yang sesuai dengan faktor-faktor yang telah dijabarkan dalam kompetensi dasar, yaitu format untuk mendesain isi pembelajaran, strategi, metode pembelajaran dan sumber pembelajaran yang akan dikembangkan.. (c) Perancangan awal. Kegiatan ini merupakan penulisan perangkat pembelajaran, yang terdiri dari (1) RPP, (2) BA, (3) LKS, dan (4) instrumen THB. Bersamaan dengan itu disusun instrumen penelitian yang akan digunakan sebagai alat pengumpul data, meliputi (1) lembar penilaian validator terhadap perangkat pembelajaran, (2) lembar uji keterbacaan untuk guru terhadap RPP, BA, dan LKS, (3) lembar uji keterbacaan untuk siswa terhadap BA dan LKS, (4) lembar observasi aktivitas guru dalam pembelajaran, (5) lembar observasi aktivitas siswa dalam pembelajaran, (6) angket respon guru terhadap perangkat pembelajaran, (7) angket respon siswa terhadap perangkat pembelajaran, dengan menggunakan perangkat PMR.

Tahap Pengembangan (Develop). Tahap ini bertujuan untuk menghasilkan perangkat pembelajaran yang baik. Ada tiga hal yang dilakukan pada tahap ini yaitu; (a) Validasi perangkat oleh pakar/ahli. Validasi

ahli untuk memperoleh perangkat pembelajaran berupa RPP, BA, dan LKS serta THB yang valid. Lembar validasi yang digunakan diadaptasi dari 
tidak homogen.

Selanjutnya untuk mengetahui ada tidaknya pengaruh pengembangan perangkat metematika realistik terhadap hasil belajar matematika materi bangun ruang sisi datar pada siswa kelas VIII SMP Katolik Ambon digunakan uji t (Sugiyono, 2012: 273). Hipotesis yang akan diuji adalah $H_{0}$ : tidak terdapat pengaruh penggunaan PMR terhadap hasil belajar siswa kelas VIII SMP Katolik Ambon, dan $H_{a}$ : terdapat pengaruh penggunaan PMR terhadap hasil belajar siswa kelas VIII SMP Katolik Ambon. Kriteria pengujian, yakni jika $t_{\text {hit }}>t_{\text {tab }}$ maka $H_{a}$ diterima dan $H_{0}$ ditolak, dan jika $t_{\text {hit }}<t_{t a b}$ maka $H_{a}$ ditolak dan $H_{0}$ diterima.

Untuk pengujian dengan uji statistik SPSS 23.0, digunakan Independent Sampel t-test dengan melihat nilai $\mathrm{p}$ (probabilitas) yang ditunjukkan oleh nilai Sig. (2-tailed). Kriteria pengambian keputusannya, yakni: jika nilai Sig. (2-tailed) < 0.05 maka $\mathrm{H}_{\mathrm{a}}$ diterima dan $\mathrm{H}_{0}$ ditolak, artinya terdapat pengaruh penggunaan PMR terhadap hasil belajar siswa kelas VIII SMP Katolik Ambon, sedangkan jika nilai Sig. (2-tailed) $>0.05$ maka $\mathrm{H}_{\mathrm{a}}$ ditolak dan $\mathrm{H}_{0}$ diterima, artinya tidak terdapat pengaruh penggunaan PMR terhadap hasil belajar siswa kelas VIII SMP Katolik Ambon.

\section{Hasil dan Pembahasan}

\subsection{Hasil Penelitian Pengembangan}

\section{Tahap Pendefinisian (Define)}

Analisis Awal-Akhir. Berdasarkan hasil wawancara dengan guru matematika yang mengajar di kelas VIII SMP Katolik Ambon dan, bahwa materi bangun ruang sisi datar, yakni menemukan dan menentukan luas permukaan dan volume dari kubus, balok, prisma, dan limas merupakan salah materi yang sulit bagi siswa. Ada kecenderungan siswa hanya menghafal rumus yang bersesuaian tanpa memahami dari mana rumusrumus tersebut diperoleh. Akibatnya siswa sering kesulitan mengerjakan soal-soal yang berkenaan dengan materi bangun ruang sisi datar. Selanjutnya diketahui bahwa pembelajaran yang selama ini dilakukan guru kurang melibatkan siswa. Guru masih menggunakan pola pembelajaran konvensional, yaitu menjelaskan konsep atau prosedur dengan sedikit tanya jawab, memberikan contoh soal, dan memberikan soal latihan, tanpa memberikan kesempatan kepada siswa untuk mengetahui bagaimana cara menemukan dan menentukan luas permukaan dan volume dari kubus, balok, prisma, dan limas dengan cara mereka sendiri. Hal ini mengakibatkan siswa tidak terbiasa membangun pengetahuan atau cara penyelesaiannya sendiri. Dalam penelitian ini, pembelajaran matematika diawali dengan masalah kontekstual, tidak dimulai dengan sistem formal, sehingga memungkinkan siswa menggunakan pengalaman atau pengetahuan yang telah dimiliki sebelumnya, selanjutnya menggunakan berbagai model situasi dan model matematika yang dibangun sendiri oleh siswa sewaktu memecahkan masalah kontekstual, siswa diberi kesempatan seluas-luasnya untuk mengembangkan berbagai strategi informal yang dapat mengarahkan pada pengkonstruksian berbagai prosedur untuk memecahkan masalah. Bentuk-bentuk interaksi seperti: negosiasi, penjelasan, pembenaran, persetujuan, pertanyaan atau refleksi digunakan untuk mencapai bentuk pengetahuan matematika formal dari bentuk-bentuk pengetahuan matematika informal yang ditemukan sendiri oleh siswa.

Salah satu pendekatan pembelajaran matematika yang mengutamakan keaktifan siswa dan menekankan pentingnya penggunaan masalah kontekstual adalah PMR. Dengan menerapkan PMR diharapkan: (1) pembelajaran tidak lagi berpusat pada guru melainkan pada siswa, (2) siswa mudah memahami materi pelajaran matematika karena dikaitkan dengan lingkungannya. Dalam hal ini guru mengutamakan keaktifan siswa dan menekankan pentingnya penggunaan masalah kontekstual sehingga akan lebih mengakrabkan matematika dengan lingkungan siswa. Dengan demikian siswa tidak mudah lupa terhadap konsep-konsep/prinsipprinsip matematika yang ia pelajari, (3) siswa dapat menerapkan materi yang telah dipelajarinya baik untuk menyelesaikan soal maupun permasalahan di kehidupan sehari-hari.

Analisis Siswa. Secara umum kemampuan siswa kelas VIII memiliki kemampuan yang bervariasi. Analisis Materi. Analisis konsep ini bertujuan untuk mendapatkan peta konsep dari Materi bangun ruang sisi datar dikembangkan berdasarkan materi matematika Kurikulum 2013 dengan sub materi luas permukaan dan volume bangun ruang sisi datar.

Analisis Tugas. Analisis tugas meliputi tugas umum dan tugas khusus. Tugas umum merujuk pada kompetensi dasar unit geometri dalam Kurikulum 2013, sedangkan tugas khusus merujuk pada indikator pencapaian hasil belajar yang dimodifikasi sesuai dengan analisis materi. Tugas umum (kompetensi dasar) KD 3.9: Membedakan dan menentukan luas permukaan dan volume bangun ruang sisi datar (kubus, balok, prisma, dan limas). KD 4.9: Menyelesaikan 
masalah yang berkaitan dengan luas permukaan dan volume bangun ruang sisi datar (kubus, balok, prisma, dan limas), serta gabungannya.

Tugas khusus (indikator pencapaian hasil belajar), yakni: a) Mengidentifikasi unsur-unsur kubus dan balok. b) Menemukan luas permukaan kubus dan balok dengan menggunakan alat peraga berupa benda nyata. c) Menyelesaikan masalah kontektual yang berkaitan dengan luas permukaan kubus dan balok. d) Menemukan luas permukaan prisma yang didapat dari penurunan rumus luas permukaan balok. e) Menemukan luas permukaan limas dengan syarat-syarat ukuran yang harus diketahui, f) Menyelesaikan masalah kontekstual yang berkaitan dengan luas permukaan prisma dan limas. g) Menemukan volume kubus dan balok melalui pola tertentu. h) Menemukan volume prisma dan limas yang didapat dari penurunan rumus volume kubus dan balok melalui pola tertentu. i) Menyelesaiakan masalah kontekstual yang berkaitan volume prisma dan limas. j) Menemukan volume prisma yang didapat dari penurunan volume kubus dan balok dengan pola tertentu. k) Menemukan volume limas yang didapat dari penurunan volume kubus dan balok dengan pola tertentu. 1) Menyelesaikan masalah kontekstual yang berkaitan dengan volume prisma dan limas.

\section{Tahap Perancangan (Design)}

Media pembelajaran yang diperlukan dalam pelaksanaan pembelajaran matematika realistik pada materi bangun ruang sisi datar di kelas VIII SMP meliputi: BA dan LKS. Beberapa alat bantu pelajaran yang diperlukan meliputi: kertas karton, gunting, papan tulis, spidol, penghapus, buku tulis dan pulpen.

Media pembelajaran Perancangan awal. Pada tahap ini dihasilkan rancangan awal RPP, BA, dan LKS untuk 4 kali pertemuan dengan alokasi waktu pertemuan I (luas permukaan kubus an balok) dan III (volume kubus dan balok) masig-masing adalah $3 \times 40$ menit sedangkan pertemuan II (luas permukaan prisma dan limas) dan IV (volume prisma dan limas) msing-masing $2 \times 40$ menit. THB disusun berdasarkan spesifikasi hasil analisis tujuan pembelajaran. Tes yang disusun berbentuk uraian yang terdiri dari 6 buitr soal. Waktu yang digunakan untuk menyelesaikan adalah 90 menit.

Pemilihan format untuk perangkat pembelajaran disesuaikan dengan prinsip, karakteristik dan langkah-langkah pembelajaran matematika realistik. Didalam rencana pembelajaran tercantum kompetensi inti (KI), kompetensi dasar (KD), indikator pencapaian kompetensi (IPK), tujuan pembelajaran, materi pokok, materi prasyarat, metode, media, sumber pembelajaran, serta kegiatan pembelajaran. Kegiatan pembelajaran terdiri dari pendahuluan, kegiatan inti, dan penutup. LKS dibuat berwarna dengan harapan siswa akan tertarik dan termotivasi belajar.

\section{Tahap Pengembangan (Develop)}

Hasil rata-rata penilaian umum yang diberikan oleh validator adalah 3,2. Maka kesimpulannya perangkat tersebut (RPP, BA, dan LKS) berada pada kriteria baik, sehingga dapat digunakan dengan sedikit revisi. Peneliti kemudian melakukan revisi terhadap semua perangkat pembelajaran berdasarkan koreksi serta saran dari para validator, yakni untuk RPP adalah bagian kegiatan penutup perlu ditambahkan dengan mengulang kembali konsep yang baru saja ditemukan dan di akhir pelajaran guru perlu menyampaikan materi untuk pertemuan selanjutya. Untuk BA yang direvisi yakni menggantikan kata merefleksikan dengan kata berbentuk, memberi penomoran pada gambar, serta ukuran huruf harus sama. Sedangkan untuk LKS, saran yang diberikan adalah mencantumkan ukuran $\mathrm{p} \mathrm{cm}, 1 \mathrm{~cm}$, dan $\mathrm{t} \mathrm{cm}$ pada gambar balok, menambahkan gambar etalase toko. Semua ini dimaksudkan agar kesederhanaan bahasa dan gambar lebih jelas dipahami siswa. Perangkat pembelajaran yang telah direvisi dinamakan draft II dan kriteria pertama yang menyatakan perangkat pembelajaran valid/baik terpenuhi.

Untuk THB, kelima validator memberikan penilaian terhadap komponen-komponen dalam THB dengan penilaian valid (V) untuk validitas isi, dapat dipahami (Dp) dan sangat dapat dipahami (Sdp) untuk bahasa dan penulisan soal, dan kesimpulan dari tes ini adalah dapat digunakan dengan revisi kecil (Rk) dan dapat digunakan tanpa revisi (Tr). Dengan demikian revisi THB disesuaikan dengan saran dari validator.

Perangkat pembelajaran dalam bentuk draft II, kemudian dilakukan uji keterbacaan kepada guru mitra yang adalah guru matematika kelas VIII-A dan 10 orang siswa kelas VIII-D SMP Kalolik Ambon. Berdasarkan hasil uji keterbacaan, maka peneliti memutuskan untuk tidak melakukan revisi terhadap perangkat pembelajaran draft II, karena perangkat pembelajaran pada draft II yang telah direvisi berdasarkan masukan validator sudah dapat terbaca dengan jelas dan dapat dipahami oleh guru mitra maupun siswa. Dengan demikian, perangkat pembelajaran draft II dapat dijadikan draft III.

Draft III kemudian diujicobakan, namun sebelumnya telah dilakukan pembagian kelompok berdasarkan hasil diskusi antara peneliti dan guru 
mitra. Dari hasil diskusi ditetapkan 28 siswa di kelas dibagi menjadi 7 kelompok, dengan tiap kelompok terdiri dari 4 orang. Pengelompokkan siswa diatur oleh guru mitra berdasarkan nilai ulangan materi sebelumnya, dan juga karena guru mitra yang lebih mengetahui kemampuan siswanya sehari-hari di kelas. Disamping itu juga dilakukan wawancara serta konsultasi dengan guru mitra untuk mengantisipasi ketidakcocokan antar siswa sehingga interaksi belajar antar siswa dalam kelompok tidak terganggu.

Hasil pengamatan terhadap guru mitra ketika menggunakan perangkat pembelajaran PMR pada keempat pertemuan, yaitu pada pertemuan I terlaksana sebesar $77,8 \%$, pertemuan II $88,9 \%$, petemuan III dan IV masing-masing $100 \%$. Dengan demikian aktivitas guru dikatakan terlaksana untuk masing-masing pertemuan. Hasil ujicoba perangkat pembelajaran pada pertemuan pertama memperlihatkan bahwa pada kegiatan inti, guru belum mengarahkan siswa untuk menemukan jawaban dan cara menjawab soal dengan memberikan bantuan terbatas, siswa belum terdorong untuk bertanya, waktu yang tersedia belum dioptimalkan. Untuk itu setelah proses pembelajaran, peneliti, pengamat, dan guru mitra melakukan diskusi membahas proses pembelajaran yang telah dilakukan dan yang akan dilakukan pada pertemuan selanjutnya. Untuk pelakasanaan ujicoba perangkat pembelajaran pada pertemuan kedua, ketiga, dan keempat secara menyeluruh dan pembelajaran berjalan sesuai lagkah-langkah pembelajaran yang ada. Hal ini dimungkinkan karena guru mitra sudah mendapat masukan dari peneliti dan pengamat. Dari proses pembelajaran yang ada dapat disimpulkan bahwa pendekatan pembelajaran matematika realistik tidak terlalu sulit dilaksanakan dan siswa terlihat aktif dalam pembelajaran.

Hasil pengamatan terhadap guru mitra ketika menggunakan perangkat pembelajaran PMR pada keempat pertemuan, yaitu pada pertemuan pertama terlaksana sebesar $77,8 \%$, pertemuan kedua $88,9 \%$, petemuan ketiga dan keempat masing-masing $100 \%$. Dengan demikian aktivitas guru dikatakan terlaksana untuk masing-masing pertemuan. Kesimpulannya bahwa guru dapat melaksanakan pembelajaran sesuai dengan perangkat PMR.

Persentase keterlaksanaan aktivitas siswa pada pertemuan I sebesar $74 \%$, pertemuan II sebesar $76 \%$, pertemuan III sebesar $78 \%$, dan pertemuan IV sebesar $78 \%$. Hal ini menunjukkan bahwa hasil yang diperoleh pada keempat pertemuan dikaregorikan dalam kualifikasi tinggi $(70 \% \leq \mathrm{Y} \leq 80 \%)$. Dengan demikian aktivitas siswa selama proses pembelajaran pada pertemuan

\section{I, II, III, dan IV dikatakan terlaksana.}

Respon guru dengan kategori sangat setuju (Ss) sebesar 76,92\%, dan setuju (S) sebesar $23,08 \%$. Sedangkan respon dengan kategori raguragu (Rr), tidak setuju (Ts), dan sangat tidak setuju (Sts) masing-masing sebesar 0\%. Dengan demikian guru memberikan respon positif sebesar $100 \%$ yang diperoleh dari penjumlahan kategori sangat setuju dan setuju. Hal ini berarti pembelajaran di kelas dikatakan terlaksana.

Rata-rata siswa memberikan respon dengan kategori sangat setuju (Ss) sebesar $84,2 \%$, setuju (S) 14,3\%, ragu-ragu (Rr) 1,5\%, dan tidak setuju (Ts) serta sangat tidak setuju (Sts) masingmasing 0\%. Dengan demikian dapatlah dikatakan bahwa siswa memberikan respon positif sebesar $98,5 \%$, yang diperoleh dari penjumlahan kategori sangat setuju dan setuju. Hal ini berarti pembelajaran di kelas dikatakan terlaksana.

Tes hasil belajar terdiri dari 6 butir soal dengan materi bangun ruang sisi datar dan diikuti oleh 28 siswa terhadap pembelajaran matematika realistik a menunjukkan bahwa $22(79 \%)$ siswa mencapai KKM ( $\geq 70)$ dan 6 (21\%) siswa belum mencapai KKM $(<70)$. Dengan demikian dapat disimpulkan bahwa hasil tes siswa telah mencapai kriteria yang telah ditentukan yaitu $\geq 65 \%$.

Berdasarkan pembahasan di atas, diketahui bahwa semua kriteria perangkat pembelajaran dikatakan valid telah terpenuhi. Ini berarti perangkat pembelajaran matematika realistik untuk materi bangun ruang sisi datar di kelas VIII SMP Katolik Ambon, yang dikembangkan oleh peneliti telah baik/valid.

\subsection{Hasil Penelitian Eksperimen}

Untuk mengetahui pengaruh pembelajaran matematika realistik terhadap hasil belajar materi bangun ruang sisi datar pada siswa kelas VIII SMP Katolik Ambon, maka setelah dilakukan pengumpulan data kemudian dianalisis menggunakan analisis statistik deskriptif dan analisis statistik inferensial. Instrumen yang digunakan dalam penelitian ini adalah tes. Sebelum tes diberikan kepada kelompok eksperimen dan kelompok kontrol, terlebih dulu harus diujikan kepada kelompok lain sebagai syarat dengan tujuan untuk mengetahui kualitas butir tes melalui validitas dan reliabilitas soal. Data hasil uji coba intrumen ini diambil dari data hasil postes kelas VIII-A sebagai kelas uji coba pada tahap pengembangan perangkat pembelajaran. Berdasarkan hasil tersebut maka semua butir tes tersebut dapat dikatakan valid sehingga layak digunakan tanpa revisi dan soal-soal tersebut adalah reliabel dengan kategori sangat tinggi. 
Dengan demikian, instrumen tes tersebut dapat digunakan tanpa revisi untuk mengukur tingkat penguasaan siswa terhadap materi bangun ruang sisi datar. pada kelompok eksperimen dan kelompok kontrol.

Selanjutnya pelaksanaan pembelajaran di kelompok eksperimen sama seperti pelaksanaan pembelajaran pada kelompok ujicoba dengan menggunakan perangkat final hasil pengembangan. Sedangkan pada kelompok kontrol, pelaksanaannya seperti biasanya guru mengajar sebelum diadakan penelitian. Dengan kata lain, pada kelompok kontrol, diberikan pembelajaran konvensional. Guru menjelaskan materi diselingi tanya jawab, sedangkan siswa mendengar, mencatat, dan menjawab pertanyaan yang diberikan guru.

Data hasil belajar dalam penelitian ini adalah data hasil belajar pretes dan postes. Pretes adalah tes yang digunakan dengan tujuan untuk mengetahui kemampuan awal siswa dari kelompok eksperimen dan kelompok kontrol sebelum diberikan perlakuan. Sedangkan postes bertujuan untuk mengetahui perbedaan hasil belajar siswa kelompok eksperimen dan kelompok kontrol setelah dilakukan atau diberikan perlakuan. Pada akhir pembelajaran siswa pada kelompok eksperimen maupun kelompok kontrol diberikan postes dengan menggunakan soal yang sama seperti pretes.

Nilai pretes kelompok eksperimen yang belum dilakukan perlakuan ditetapkan sebagai nilai awal dengan rata-rata 24,66 dan setelah dilakukan metode eksperimen diperoleh rata-rata postes 75,11 . Nilai pretes pada kelompok kontrol dengan rata-rata 25,79 dan setelah diberikan perlakuan yaitu metode konvensional maka nilai postes pada kelompok kontrol 67,00. Perbedaan nilai pretes dan postes di kelompok eksperimen memiliki selisih 50,45 sedangkan perbedaan nilai pretes dan postes di kelompok kontrol memiliki selisih 41,21. Dengan perbedaan besaran selisih antara kelompok eksperimen dan kelompok kontrol yang didapat, bahwa peningkatan hasil belajar di kelompok eksperimen lebih baik dari pada kelompok kontrol.

Sebelum dilaksanakan uji hipotesis, dilakukan uji prasyarat yakni uji normalitasdan uji homogenitas. Uji normalitas terhadap dua kelompok tersebut dilakukan dengan uji ShapiroWilk menggunakan program SPSS 23 for Windows dengan taraf signifikansi 0,05 , menunjukkan bahwa nilai Sig untuk kelompok eksperimen 0,189 $>0,05$ dan nilai Sig untuk kelompok kontrol 0,077 $>0,05$. Hal ini berarti sampel yang diambil berasal dari populasi yang berdistribusi normal.
Sedangkan untuk uji homogenitas dilakukan dengan uji Levene dan diperoleh nilai signifikansinya adalah 0,367 . Karena nilai signifikansinya $>0,05$, maka dapat disimpulkan bahwa siswa kelompok eksperimen dan kelompok kontrol berasal dari populasi yang mempunyai varians yang sama, atau kedua kelompok tersebut homogen.

Selanjutnya untuk pengujian hipotesis dari hasil output disimpulkan bahwa $\mathrm{H}_{\mathrm{a}}$ diterima dan $\mathrm{H}_{0}$ ditolak, karena Sig. (2-tailed) $<0,05$ yaitu, $0,015<0,05$ artinya bahwa hasil belajar siswa kelompok eksperimen yang menggunakan pembelajaran matematika realistik berbeda dengan hasil belajar siswa kelompok kontrol yang menggunakan pembelajaran konvensional. Dengan demikian dapat disimpulkan bahwa penggunaan pembelajaran matematika realistik dalam pembelajaran berpengaruh terhadap hasil belajar matematika pada siswa kelas VIII SMP Katolik Ambon.

\section{Kesimpulan}

Berdasarkan tujuan penelitian maka dapat disimpulkan bahwa: 1) Perangkat pembelajaran matematika realistik (PMR) yaitu, RPP, BA, dan LKS pada materi bangun ruag sisi datar untuk siswa kelas VIII SMP Katolik Ambon memenuhi kriteria baik/valid, setelah: divalidasi, dilakukan uji keterbacaan dan diujicobakan. 2) Ada pengaruh pengembangan perangkat pembelajaran matematika realistik terhadap hasil belajar matematika untuk materi bangun ruang sisi datar pada siswa kelas VIII SMP Katolik Ambon. Hipotesis tersebut diterima karena Sig. (2-tailed) $<0,05$, yakni $0,015<0,05$.

\section{Daftar Pustaka}

Abdurrahman. 2002. "Pengembangan Perangkat Pembelajaran Penemuan Terbimbing pada Topik Bengun-bangun Segiempat di Kelas 2 SLTP Negeri 16 Pekanbaru”. Makalah Komprehensif. Surabaya: PPs Universitas Negeri Surabaya.

Hobri. 2008. Model-model Pembelajaran Inovatif. Jember: Universitas Jember.

Kesek, M. 2009. Pengaruh Pembelajaran Matematika Realistik terhadap Hasil Belajar Materi Pokok Barisan Bilangan Kelas IX SMP Negeri 1 Amurang. Skripsi, Program Studi Pendidikan Matematika Jurusan Matematika, FMIPA: Universitas Negeri Manado. Diakses pada tanggal 22 Nopember 2018.

Mursalin. 2016. Pembelajaran Geometri Bidang Datar Di Sekolah Dasar Berorientasi Teori Belajar Piaget. Jurnal Dikma 4(2). Hlm 250-258. 
Ratumanan, T.G. 2016. Inovasi Pembelajaran, (Edisi ke-2). Bandung: Alfabeta.
Suyitno, A. 2004. Dasar-dasar Proses Pembelajaran 1. Semarang: UNNES Press 